\title{
Mechanism of liquefaction of the human ejaculate II. Role of collagenase-like peptidase and seminal proteinase
}

\author{
J. Lukač and E. Koren \\ Laboratory for Experimental Medicine, Faculty of Pharmacy and Biochemistry, University of \\ Zagreb, Domagojeva 2, 41000 Zagreb, Yugoslavia
}

\begin{abstract}
Summary. Collagenase-like peptidase and seminal proteinase were isolated from human testis and human seminal plasma. The effects of both enzymes upon proteins isolated from the human ejaculate were studied. Both enzymes degraded ejaculate proteins. The data suggest that collagenase-like peptidase is responsible for the first, and seminal proteinase for the second, phase of human ejaculate liquefaction in vitro.
\end{abstract}

\section{Introduction}

The liquefaction of the human ejaculate has been described in several reports as the result of proteolytic degradation of the ejaculate proteins. Participation of several proteolytic enzymes (fibrinolysin, plasminogen activators, seminal proteinase, seminal aminopeptidase) has been proposed (Huggins \& Neal, 1942; Harvey, 1949; Oettlé, 1950; Lundquist, 1952; Lundquist, Thorsteinsson \& Buus, 1955; Von Kaulla \& Shettles, 1953). This hypothesis is based upon the fact that human seminal plasma is capable of splitting various synthetic substrates for proteolytic enzymes (Lundquist et al., 1955) as well as upon its ability to dissolve human blood clots and fibrin plates (Huggins \& Neal, 1942; Harvey, 1949; Von Kaulla \& Shettles, 1953; Lundquist et al., 1955; Suominen, Eliasson \& Niemi, 1971). However, there is no direct evidence about the action of proteolytic enzymes from human seminal plasma against human ejaculate proteins although a sperm collagenase-like peptidase was proved to degrade ejaculate proteins in the rat (Koren, Lukač \& Milković, 1974; Koren, Schön \& Lukač, 1975).

In this work evidence is presented that collagenase-like peptidase (EC 3.4.4.19) from human testis and human ejaculate plays an important role in the liquefaction process by degrading human ejaculate proteins. In addition to participation of collagenase-like peptidase, the role of seminal proteinase in the liquefaction is also clarified.

\section{Materials and Methods}

Chemicals. Synthetic PZ-pentapeptide(4-phenylazo-benzyloxy-carbonyl-L-prolyl-L-leucyl-Lglycyl-L-prolyl-D-arginine) and PZ-dipeptide(4-phenylazo-benzyloxy-carbonyl-L-prolyl-L-leucine) were purchased from Fluka, Buchs, Switzerland. N-benzoil-D,L-arginine- $p$-nitroanilide $\mathrm{HCl}$ (BAPA), alpha-casein, ethylenediaminetetra-acetate, $\mathrm{Na}_{2}$ (EDTA), 1, 10-phenantroline and Silica-gel $\mathrm{G}$ were obtained from Merck, Germany; $p$-Tosyl-L-arginine methylester HCl (TAME) was from the Koch-Light Laboratories, England; bovine serum albumin (monomer) was from Calbiochem, U.S.A.; cytochrome $C$ was from NBC, U.S.A.; and dextran blue was from Pharmacia, Sweden. 
Biological material. Human testes were obtained from the Institute for Forensic Medicine, School of Medicine, University of Zagreb. The testes were taken from men aged 20 to 40 years, who had died in traffic accidents, within $6 \mathrm{~h}$ after death.

Human semen was collected from healthy young volunteers by manual masturbation.

Purification of the enzymes. Collagenase-like peptidase (CLP) from human testis was purified as described previously (Koren et al., 1974) for CLP from rat testis. Purification of CLP and seminal proteinase (SP) from seminal plasma was performed by gel filtration on a Sephadex G-200 column. After $30 \mathrm{~min}$ of liquefaction at room temperature the ejaculate was centrifuged for $30 \mathrm{~min}$ at $10000 \mathrm{~g}$ and $0^{\circ} \mathrm{C}$. The supernatant $(80 \mathrm{ml})$ was passed through a Sephadex G200 column $(80 \times 2.5 \mathrm{~cm})$, equilibrated and eluted with $0.05 \mathrm{M}$ Tris-acetate buffer, $\mathrm{pH} 7.5$, containing $0.05 \mathrm{M}-\mathrm{NaCl}$, at the flow rate of $12 \mathrm{ml} / \mathrm{h}$. In each of the $6-\mathrm{ml}$ fractions the protein concentration, CLP and SP activity were determined.

Enzyme assays. CLP activity was determined according to the method of Wünsch \& Heidrich (1963) using synthetic PZ-pentapeptide as a substrate. The degradation product, PZdipeptide was identified also by thin-layer chromatography on silica gel $\mathrm{G}$ using a solvent system of $n$-butanol :acetic acid :pyridine : water (25:5:11:20 by vol.) and PZ-dipeptide and PZ-pentapeptide as standards. SP activity was measured according to the method of Syner \& Moghissi (1972) using alpha-casein as a substrate (see Koren \& Milković, 1973). Amidase activity was estimated by the method of Erlanger, Kokowsky \& Cohen (1961) using BAPA as a substrate. Esterase activity was determined by the method of Walsh (1970) using TAME as a substrate.

The effect of CLP on the 'recoagulum'. The frozen 'recoagulum' prepared as described by Koren \& Lukač (1979) was divided into several parts and weighed. To each $500 \mathrm{mg}$ of the 'recoagulum' $0.5 \mathrm{ml} \mathrm{CLP}$ solution was added. In the control samples $0.5 \mathrm{ml} 0.05 \mathrm{M}$-Tris-acetate buffer, $\mathrm{pH} 7 \cdot 5$, containing $0.05 \mathrm{M}-\mathrm{NaCl}$ was added instead of enzyme solution. Incubation was performed at $37^{\circ} \mathrm{C}$ for $3 \mathrm{~h}$. The changes occurred were observed macroscopically, by electron microscopy and by disc electrophoresis.

The effect of SP on solubilized 'recoagulum' proteins. A $0.5-\mathrm{ml}$ volume of 'recoagulum' solubilized by CLP was mixed with $0.5 \mathrm{ml}$ of SP solution and incubated for $3 \mathrm{~h}$ at $37^{\circ} \mathrm{C}$. The activity of SP was estimated as above and disc electrophoresis of the incubation mixture was also performed.

Molecular weight determination. The molecular weight of CLP seminal proteinase was determined after gel filtration on Sephadex G-200, by the $V_{\mathrm{e}} / V_{0}$-log molecular weight plot. The column $(30 \times 1.5 \mathrm{~cm})$ was calibrated with bovine serum albumin (mol. wt $6.8 \times 10^{4}$ ), cytochrome $\mathrm{C}$ (mol. wt $1.3 \times 10^{4}$ ) and potassium dichromate (mol. wt $2.9 \times 10^{2}$ ).

Disc electrophoresis was performed by the method of Reisfeld, Lewis \& Williams (1962) at $7 \cdot 5 \%$ polyacrylamide concentration and $\mathrm{pH} 8 \cdot 3$.

Proteins were determined according to the method of Lowry, Rosebrough, Farr \& Randall (1951) using bovine serum albumin as a standard.

\section{Results}

Purification of collagenase-like peptidase (CLP) and seminal proteinase (SP) from the human seminal plasma by gel filtration on Sephadex G-200 column is shown in Text-fig. 1. CLP activity was found in peak II (mol. wt approx. 55 000) and SP activity in peak III (mol. wt approx. 24 000) (Text-fig. 2). By gel filtration CLP was purified 36 times and SP 16 times (Table 1). Table 2 shows the result of CLP purification from human testis by acetone precipitation yielding a 15 times purified enzyme. Table 3 shows the effect of metallic cations and chelating agents on CLP activity towards synthetic substrate. $\mathrm{Zn}^{++}, \mathrm{Hg}^{++}$and $\mathrm{Cu}^{++}$were strong inhibitors, $\mathrm{Co}^{++}$caused partial inhibition, while $\mathrm{Ca}^{++}$and $\mathrm{Mn}^{++}$showed no effect. Chelating agents inhibited CLP 
activity. The enzymes from both sources showed the same properties. The SP activity was not affected by metallic cations and chelating agents in the concentrations tested (Table 4). Neither enzyme preparation degraded BAPA or TAME.

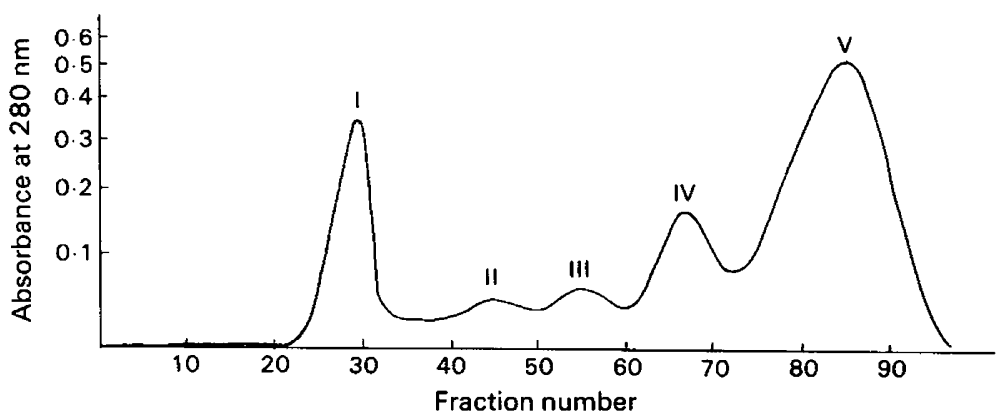

Text-fig. 1. Gel filtration of $8 \mathrm{ml}$ human seminal plasma on Sephadex G-200 $(80 \times 2.5 \mathrm{~cm})$. The CLP activity was found in peak II and the SP activity in peak III.

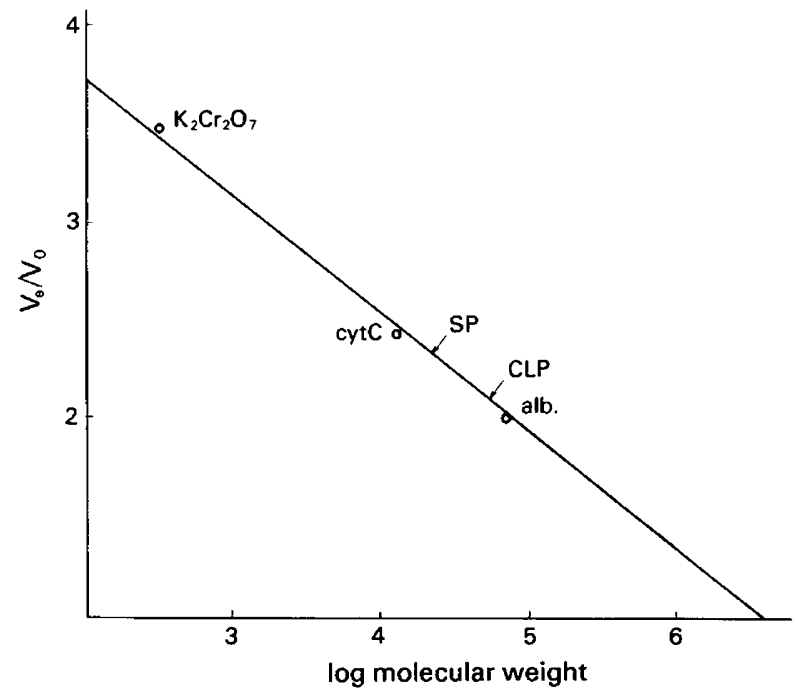

Text-fig. 2. Determination of molecular weight of CLP and SP (arrows) by assessment against a calibration curve of known proteins on a Sephadex G-200 column $(30 \times 1.5 \mathrm{~cm})$. alb = bovine serum albumin; cytC $=$ cytochrome $\mathrm{C}$.

Table 1. The activities (mean \pm s.e.m., no. of samples in parentheses) of collagenase-like peptidase (CLP) and seminal proteinase (SP) in seminal plasma and in the fractions obtained by gel filtration of seminal plasma on Sephadex G-200

\begin{tabular}{|c|c|c|c|c|c|}
\hline & \multirow[b]{2}{*}{$\begin{array}{c}\text { Protein conc. } \\
\text { (mg/ml incubation } \\
\text { mixture) }\end{array}$} & \multicolumn{2}{|c|}{$\begin{array}{c}\text { CLP activity } \\
\text { ( } \mu \mathrm{g} \text { PZ-dipeptide released) }\end{array}$} & \multicolumn{2}{|c|}{$\begin{array}{c}\text { SP activity } \\
\text { ( } \mu \mathrm{g} \text { tyrosine released) }\end{array}$} \\
\hline & & $\begin{array}{c}\text { Total } \\
\text { (/ml incubation } \\
\text { mixture })\end{array}$ & $\begin{array}{c}\text { Specific } \\
\text { (/mg protein) }\end{array}$ & $\begin{array}{c}\text { Total } \\
\text { (/ml incubation } \\
\text { mixture })\end{array}$ & $\begin{array}{c}\text { Specific } \\
\text { (/mg protein) }\end{array}$ \\
\hline Seminal plasma & $\begin{array}{c}23 \cdot 5 \pm 3 \cdot 5 \\
(11)\end{array}$ & $\begin{array}{c}13 \cdot 5 \pm 3 \cdot 1 \\
(11)\end{array}$ & 0.57 & $113 \cdot 0 \pm 22 \cdot 1$ & 4.8 \\
\hline Peak II (CLP) & $0.254 \underset{(9)}{ \pm 0.052}$ & $\begin{array}{c}5 \cdot 3 \pm 0 \cdot 7 \\
(11)\end{array}$ & $20 \cdot 8$ & $1.9 \pm \frac{0.2}{(6)}$ & 7.5 \\
\hline Peak III (SP) & $0.299 \pm 0.056$ & $0.8 \pm 0.2$ & $2 \cdot 7$ & $\begin{array}{c}22 \cdot 5 \pm 1 \cdot 3 \\
(11)\end{array}$ & $75 \cdot 3$ \\
\hline
\end{tabular}


Table 2. Protein concentration, total CLP activity and specific CLP activity during the purification process of CLP from human testis (mean \pm s.e.m.)

\begin{tabular}{|c|c|c|c|c|}
\hline Fractions & $\begin{array}{c}\text { No. of } \\
\text { samples }\end{array}$ & $\begin{array}{l}\text { Protein conc. } \\
\text { (mg/ml incubation } \\
\text { mixture) }\end{array}$ & $\begin{array}{l}\text { Total CLP activity } \\
(\mu \mathrm{g} \text { PZ-dipeptide } \\
\text { released/ml } \\
\text { incubation mixture) }\end{array}$ & $\begin{array}{l}\text { Specific CLP activity } \\
\text { ( } \mu \mathrm{g} \text { PZ-dipeptide } \\
\text { released } / \mathrm{mg} \\
\text { protein })\end{array}$ \\
\hline Homogenate & 5 & $6.87 \pm 0.12$ & $56 \cdot 76 \pm 7.99$ & $8 \cdot 26$ \\
\hline \multicolumn{5}{|c|}{ Acetone fractions } \\
\hline $0-30 \%$ & 4 & $5.60 \pm 0.47$ & $4.72 \pm 0.61$ & 0.84 \\
\hline $30-50 \%$ & 4 & $12.68 \pm 1.39$ & $42.70 \pm 5.88$ & $3 \cdot 37$ \\
\hline $50-65 \%$ & 9 & $0.72 \pm 0.05$ & $89.10 \pm 6.78$ & 123.40 \\
\hline
\end{tabular}

Table 3. The effect of metallic cations and chelating agents on the activity of CLP purified from human testis by acetone precipitation and from human seminal plasma by gel filtration on Sephadex G-200

\begin{tabular}{lcccc}
\hline & & \multicolumn{3}{c}{$\%$ of activity } \\
\cline { 3 - 5 } Agent added* & $\begin{array}{c}\text { Conc. of agent } \\
(\mathrm{M})\end{array}$ & $\begin{array}{c}\text { CLP from human } \\
\text { testis }\end{array}$ & $\begin{array}{c}\text { CLP from human } \\
\text { seminal plasma }\end{array}$ & No. of samples \\
\hline- & - & 100 & 100 & 11 \\
$\mathrm{Zn}^{++}$ & $10^{-4}$ & 14 & 31 & 9 \\
$\mathrm{Cu}^{++}$ & $10^{-4}$ & 11 & 22 & 6 \\
$\mathrm{Hg}^{++}$ & $10^{-4}$ & 9 & 26 & 8 \\
$\mathrm{Co}^{++}$ & $10^{-4}$ & 81 & 62 & 9 \\
$\mathrm{Ca}^{++}$ & $10^{-3}$ & 110 & 96 & 6 \\
$\mathrm{Mn}^{++}$ & $10^{-3}$ & 105 & 94 & 6 \\
$\mathrm{Na}_{2}$ EDTA & $10^{-2}$ & 43 & 26 & 6 \\
1,10 -Phenantroline & $10^{-3}$ & 34 & 28 & \\
\hline
\end{tabular}

* All metal salts were in chloride form.

The effect of CLP on the 'recoagulum' is shown in PI. 1, Figs 1 and 2. CLP caused macroscopically visible lysis of the 'recoagulum'. The lysis was accompanied by the appearance of 11 protein fractions, shown by disc electrophoresis (Pl. 1, Fig. 3). The 'recoagulum' underwent the same changes during the incubation with testicular CLP.

As shown in Pl. 1, Fig. 3, CLP did not degrade solubilized proteins of the 'recoagulum'. However, SP did degrade these proteins (Pl. 1, Fig. 3), releasing TCA-soluble peptides, the values (mean \pm s.e.m., $n=4$ ) being $20.6 \pm 1.9$ and $21.5 \pm 2.7$ in buffer and 18.9 to 0.9 and $120.3 \pm 18 \cdot 1 \mu \mathrm{g}$ tyrosine released $/ \mathrm{ml}$ incubation mixture with seminal proteinase before and after, respectively, a 3-h incubation.

\section{PLATE 1}

Fig. 1. 'Recoagulum' at the beginning of incubation in CLP solution at $37^{\circ} \mathrm{C}$ and $\mathrm{pH} 7 \cdot 5 . \times 40$.

Fig. 2. 'Recoagulum' after $30 \mathrm{~min}$ of incubation in CLP solution at $37^{\circ} \mathrm{C}$ and $\mathrm{pH} 7 \cdot 5 . \times 40$.

Fig. 3. Disc electropherograms of incubation mixture containing: (A) 'recoagulum' and CLP solution, at the beginning of incubation at $37^{\circ} \mathrm{C}$ and $\mathrm{pH} 7.5$; (B) 'recoagulum' and CLP solution after $30 \mathrm{~min}$ of incubation, i.e. after macroscopically visible lysis of the 'recoagulum', showing 11 protein fractions almost identical to those found after the first phase of liquefaction of the intact ejaculate; (C) 'recoagulum' and CLP solution after $3 \mathrm{~h}$ of incubation; there were no further changes; (D) solubilized proteins of the 'recoagulum' and SP solution after $3 \mathrm{~h}$ of incubation. 
PLATE 1
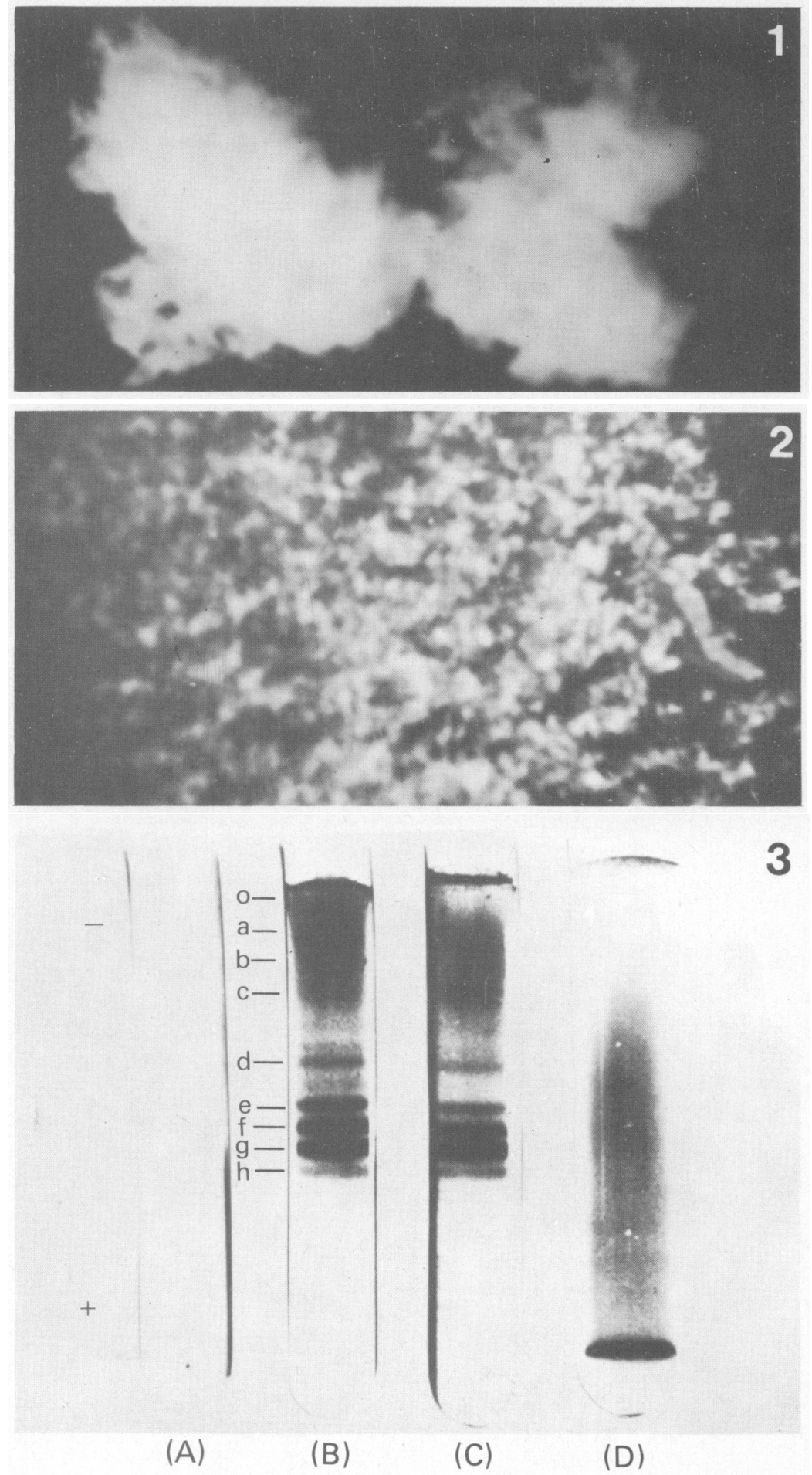

(Facing p. 504) 
PLATE 2

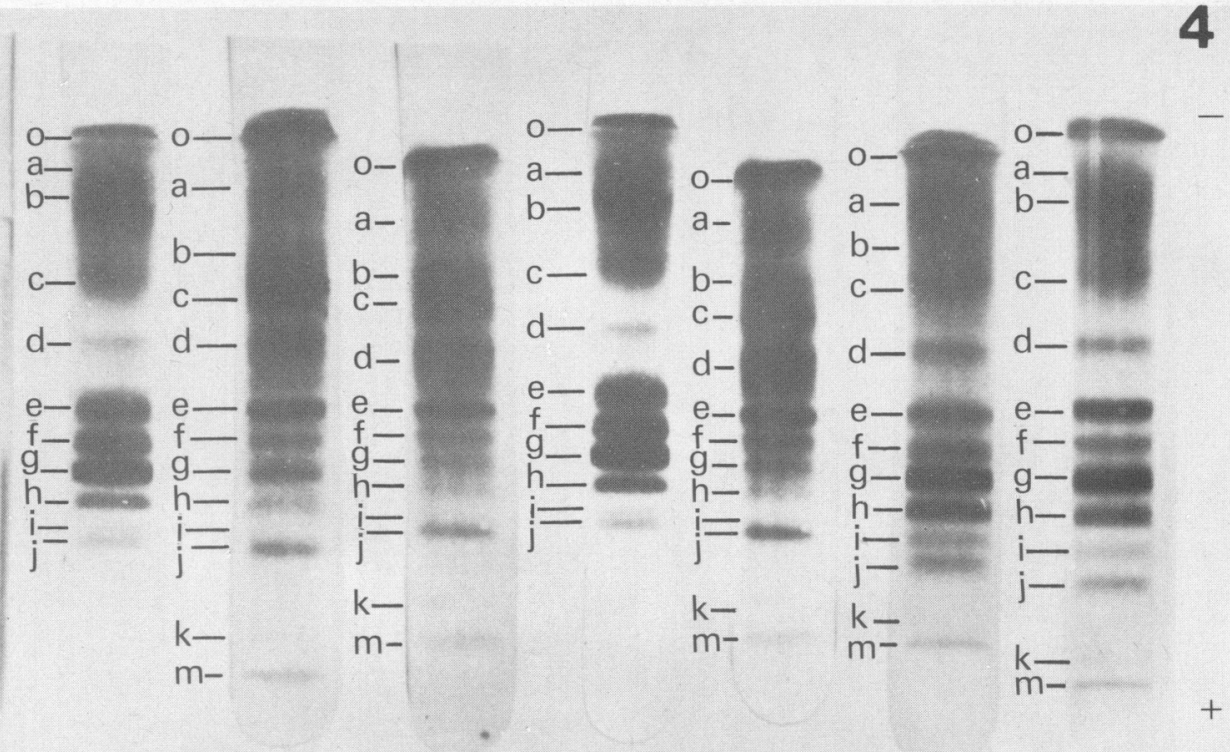
A
B
C
D
E
F
G
$\mathrm{H}$
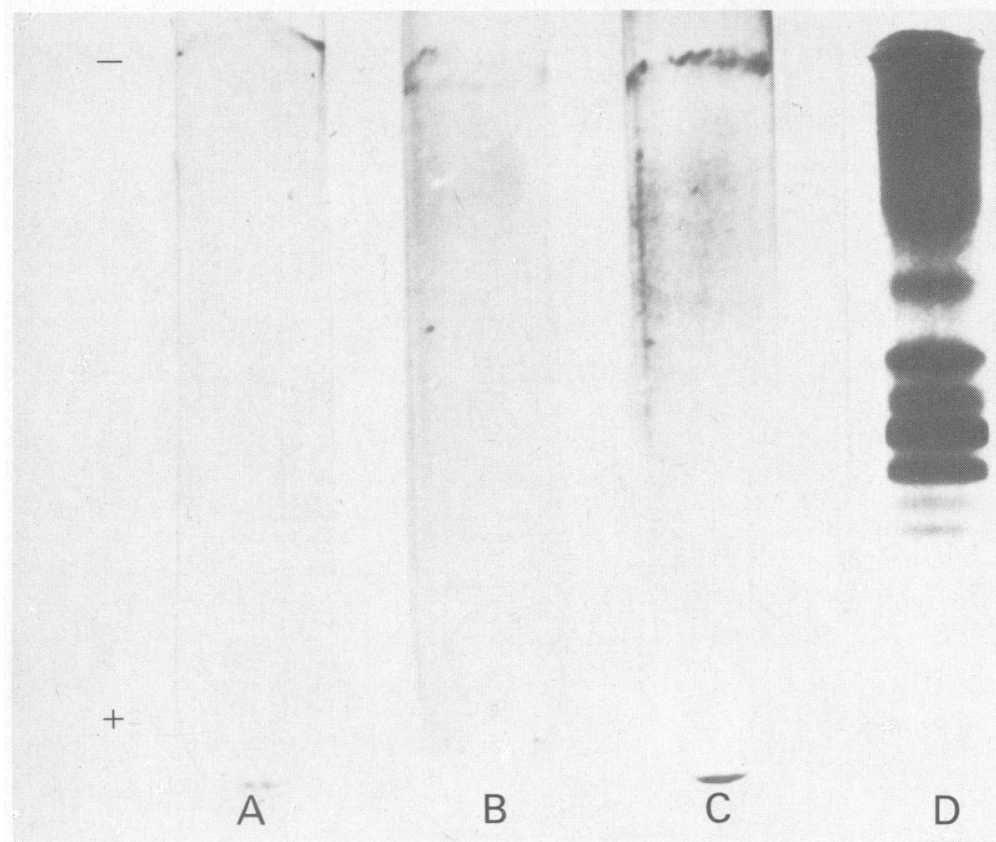

5 
Table 4. The effect of metallic cations and chelating agents on the activity of seminal proteinase purified from human seminal plasma by gel filtration on Sephadex G-200

\begin{tabular}{lccc}
\hline Agent added & $\begin{array}{c}\text { Conc. of agent } \\
\text { (M) }\end{array}$ & $\begin{array}{c}\text { \% of seminal } \\
\text { proteinase activity }\end{array}$ & No. of samples \\
\hline- & - & 100 & 11 \\
$\mathrm{Zn}^{++}$ & $10^{-4}$ & 109 & 6 \\
$\mathrm{Cd}^{++}$ & $10^{-4}$ & 100 & 4 \\
$\mathrm{Co}^{++}$ & $10^{-4}$ & 116 & 4 \\
$\mathrm{Ca}^{++}$ & $10^{-3}$ & 105 & 4 \\
$\mathrm{Mn}^{++}$ & $10^{-3}$ & 106 & 6 \\
$\mathrm{Na}_{2}$ EDTA & $5 \times 10^{-3}$ & 95 & 6 \\
1,10 -Phenantroline & $10^{-3}$ & 120 & 6 \\
\hline
\end{tabular}

* All metal salts were in chloride form.

\section{Discussion}

The process of liquefaction of the human ejaculate was in early works ascribed to a fibrinolytic system similar to that in blood (Huggins, \& Neal, 1942; Lunquist, 1952; Lundquist et al., 1955). However, evidence has accumulated in recent reports (Suominen \& Niemi, 1970; Tauber, Zaneveld, Propping \& Schumacher, 1976; Koren \& Lukač, 1979) which points to a dissimilarity between the ejaculate proteolysis and fibrinolysis. Moreover, the precise mechanism of liquefaction cannot be explained only by the presence of proteolytic enzymes and the appearance of degradation products such as peptides and amino acids in seminal plasma (Lundquist, 1952). In this study we tried to reconstitute the liquefied ejaculate in vitro in order to make the investigation of the liquefaction mechanism easier. The enzymes (CLP and SP) were separated and partly purified in the usual way while substrate proteins were separated in the form of the 'recoagulum'. In our opinion the 'recoagulum' should be considered as an appropriate biological substrate for ejaculate proteases because it contains native ejaculate proteins. Moreover, the 'recoagulum' does not liquefy spontaneously and its substructure appears to be the same as in the intact ejaculate except for the lack of spermatozoa (Koren \& Lukač, 1979). Assuming that the 'recoagulum' represents a natural substrate for ejaculate proteases it would appear that CLP is indispensable for the first phase of liquefaction. On the one hand, CLP causes a macroscopically visible liquefaction of the 'recoagulum' (Pl. 1, Fig. 2) and on the other, protein fractions released during 'recoagulum' lysis by CLP are identical to those released after the first phase of spontaneous liquefaction of the intact ejaculate (Pl. 1, Fig. 3). Moreover, CLP-mediated 'recoagulum' liquefaction is characterized by the disappearance of its globular substructure which is also the case in the first phase of liquefaction of the intact ejaculate (Koren \& Lukač, 1979). The fact that $\mathrm{Zn}^{++}, \mathrm{Cu}^{++}$and $\mathrm{Hg}^{++}$completely inhibit the first phase of liquefaction (Koren \& Lukač, 1979) and also the CLP activity towards synthetic PZ-pentapeptide (Table 3) favours the above hypothesis.

CLP does not exert any further effect on proteins once released from the 'recoagulum' (Pl. 1, Fig. 3) and its participation in the later phases of liquefaction is unlikely. Further degradation of proteins released from the 'recoagulum' was achieved by seminal proteinase. This enzyme, described in several reports (Lundquist et al., 1955; Syner \& Moghissi, 1972), is believed to participate in the process of liquefaction (Lundquist et al., 1955). According to the results in the present work, seminal proteinase is involved in the second phase of liquefaction.

This work was supported by research grant No. 760-0324 from the Ford Foundation, New York, N.Y., and by Self-managing Authority for Scientific Research of SR Croatia. 


\section{References}

Erlanger, B.F., Kokowsky, N. \& Cohen, W. (1961) Preparation and properties of two new chromogenic substrates of trypsin. Archs biochem. Biophys. 95, 271279.

Harvey, C. (1949) Fibrinolysin in human semen. A method of assay and some preliminary observations. Proc. Soc. Study Fertil. 1, 11-27.

Huggins, Ch. \& Neal, W. (1942) Coagulation and liquefaction of semen. Proteolytic enzymes and citrate in prostatic fluid. J. exp. Med. 76, 527-541.

Koren, E. \& Lukač, J. (1979) Mechanism of liquefaction of the human ejaculate. I. Changes of the ejaculate proteins. J. Reprod. Fert. 56, 493-499.

Koren, E. \& Milković, S. (1973) Collagenase-like peptidase in human, rat and bull spermatozoa. $J$. Reprod. Fert. 32, 349-356.

Koren, E., Lukač \& Milković, S. (1974) The effect of collagenase-like peptidase from rat testis and clostridial collagenase on the rat seminal vesicle secretion and its coagulation. J. Reprod. Fert. 36, 161167.

Koren, E., Sehön, E. \& Lukač, J. (1975) The coagulation of insoluble and basic protein from rat seminal vesicle secretion with vesiculase: influence of collagenaselike peptidase from rat testis. J. Reprod. Fert. 42, 491-495.

Lowry, O.H., Rosebrough, N.Y., Farr, A.L. \& Randall, R.J. (1951) Protein measurement with the folin phenol reagent. J. biol. Chem. 193, 265-275.

Lundquist, F. (1952) Studies on the biochemistry of human semen. IV. Amino acids and proteolytic enzymes. Acta physiol. scand. 25, 178-187.
Lundquist, F., Thorsteinsson, Th. \& Buus, O. (1955) Purification and properties of some enzymes in human seminal plasma. Biochem. J. 59, 69-79.

Oettlé, A.G. (1950) Fibrinolytic factors in human semen. Proc. Soc. Study Fertil. 2, 71.

Reisfeld, R.A., Lewis, V.J. \& Williams, D.E. (1962) Disc electrophoresis of basic proteins and peptides on polyacrylamide gels. Nature, Lond. 195, 281-290.

Suominen, H. \& Niemi, M. (1970) Proteolytic enzymes in human seminal fluid. Scand. J. clin. lab. Invest. 25, Suppl. 113, 52.

Suominen, J., Eliasson, R. \& Niemi, M. (1971) The relation of the proteolytic activity of human seminal plasma to various semen characteristics. $J$. Reprod. Fert. 27, 153-156.

Syner, F.N. \& Moghissi, K.S. (1972) Purification and properties of a human seminal proteinase. Biochem. J. 126, 1135-1140.

Tauber, P.F., Zaneveld, L.H.D., Propping, D. \& Schumacher, G.F.B. (1976) Components of human split ejaculates. II. Enzyme and proteinase inhibitors. J. Reprod. Fert. 46, 165-171.

Von Kaulla, K.N. \& Shettles, L.B. (1953) Relationship between human seminal fluid and the fibrinolytic system. Proc. Soc. exp. Biol. Med. 83, 692-694.

Walsh, K.A. (1970) Methods of assay of trypsin. In Methods in Enzymology, Vol. 19, pp. 43-44. Eds S. P. Collowick \& N. O. Kaplan. Academic Press, New York.

Wünsch, E. \& Heidrich, H.G. (1963) Zur quantitativen Bestimmung der Kollagenase. Hoppe-Seyler's $Z$. Physiol. Chem. 3, 149-153.

Received 25 September 1979 